\title{
Responses of a translocated howler monkey Alouatta palliata group to new environmental conditions
}

\author{
Aralisa Shedden-González*, Ernesto Rodríguez-Luna \\ Centro de Investigaciones Tropicales, Universidad Veracruzana, Exhacienda Lucas Martín, Calle Araucarias s/n, \\ Col. Periodistas C.P. 91019 Xalapa, Veracruz, Mexico
}

\begin{abstract}
Considering the drastic changes in primate habitats, we must search for management strategies to maintain primate populations in the wild. In the present study, a group of howler monkeys Alouatta palliata was followed after being translocated to a 90 ha tropical forest used for understory palm Chamaedorea elegans cultivation. The group's behavior was recorded in the new environment. There was no evidence of behavioral alterations due to the different habitat conditions, the translocation process or the palm cultivation activities at the release site. These results indicate that reintroduction, even to fragments used for cultivation purposes, is a viable conservation approach for howler monkey conservation in the Los Tuxtlas region of Mexico.
\end{abstract}

KEY WORDS: Adaptive responses · Alouatta palliata $\cdot$ Conservation $\cdot$ Mexico $\cdot$ Reintroduction

Resale or republication not permitted without written consent of the publisher

\section{INTRODUCTION}

The conversion of ecosystems for farming, plantations and urban or suburban developments is reducing a diverse range of habitats (Soulé \& Orians 2001). In the Los Tuxtlas region of Veracruz, Mexico, numerous economic, social, cultural, legal and political factors contribute to the destruction of original vegetation (Guevara et al. 2004). This situation threatens primate populations in the area, such as those of Alouatta palliata mexicana, listed as Critically Endangered by the IUCN (Cuarón et al. 2008).

In response to the growing pressure on species and ecosystems, it is important to find ways to ensure habitat and species viability in a landscape with permanent human presence and influence. Translocation is one technique used to restore or supplement animal (Griffith et al. 1989, Olney et al. 1994, Serena 1995, IUCN SSC 2002) or plant populations (Allen 1994, Primack 1996). Following such intervention, the demography, behavior and ecology, changes in reproductive strategies, mortality and group stability of the population should be monitored in order to determine whether the translocation or reintroduction has been successful (IUCN SSC 2002). Certain site characteristics can facilitate the objectives of a translocation or reintroduction (ensuring long-term persistence of the released animals). These include the protection and maintenance of habitats. Also, the site where animals ought to be released should be within the natural distribution of the species (Griffith et al. 1989). Sites that are used for sustainable and economic cultivation may allow us to determine if species conservation is compatible with benefits for local inhabitants, and can be used as an ecological-economical model for future conservation activities.

Since natural landscapes are in constant transformation, the need to study primates in altered habitats or those which are undergoing changes is urgent (Onderdonk \& Chapman 2000, Bicca-Marques 2003, Cristóbal-Azkarate \& Arroyo-Rodríguez 2007, IsabiryeBasuta \& Lwanga 2008). Considering this situation, we evaluated the adjustment of a group of howler monkeys Alouatta palliata to new habitat conditions. The following behavioral aspects have been suggested as indicators for the capacity of howler monkeys to 
adapt to a new environment: (1) diet (Estrada \& Coates-Estrada 1996, Kowalewski \& Zunino 1999, Juan et al. 2000, Rodríguez-Luna et al. 2003); (2) spatial use (Milton 1980, Estrada \& Coates-Estrada 1996, Crockett 1998, Clarke et al. 2002); and (3) daily activity pattern (Loudon 2000, Juan et al. 2000, CristóbalAzkarate \& Arroyo-Rodríguez 2007). Furthermore, since forest fragments play an increasingly important role in howler monkey conservation (Bicca-Marques 2003), and there is an urgency to increase, connect and maintain these fragments by involving local communities (Mandujano et al. 2006), it is crucial to determine if fragment use for economic purposes and endangered species conservation are compatible.

\section{MATERIALS AND METHODS}

We followed a group of howler monkeys after they were released at a site used for sustainable parlour palm Chamaedorea elegans cultivation. This research project formed part of the Primate Translocation Program managed by the Universidad Veracruzana, Mexico. Four individuals were captured from a 4.9 ha fragment, situated in the southern part of Veracruz State, Mexico. The fragment is completely surrounded by pastures and cultivation areas and its vegetation is mainly composed of Scheelea liebmanii palms, as well as some individuals of Lonchocarpus guatemalensis and Albizia purpusii (Aguilar-Cucurachi 2007). After capture, the monkeys were kept in quarantine ( $35 \mathrm{~d}$ ) and were under constant observation until their release.

Study area. The study area (Flor de Catemaco) is located in Catemaco, Veracruz, Mexico, in an area surrounding the buffer zone of Los Tuxtlas Biosphere Reserve $\left(18^{\circ} 26^{\prime} 00^{\prime \prime}\right.$ to $18^{\circ} 26^{\prime} 27^{\prime \prime} \mathrm{N}$ and $95^{\circ} 02^{\prime} 30^{\prime \prime}$ to $\left.95^{\circ} 03^{\prime} 30^{\prime \prime} \mathrm{W}\right)$. This site was selected since it is well protected by owners and the geographical location is within the natural distribution of this species of howler monkey. The study site is composed of approximately 90 ha of semi-deciduous tropical forest, and its understory is used for cultivating sustainable plantations of parlour palm. All palm maintenance activities are oriented to reduce impact on the environment, but require constant human presence.

Study group. The group consisted of 4 ind.: 1 adult female, 1 subadult female, 1 adult male and 1 subadult male.

Vegetation characteristics. Quadrants of $25 \times 25 \mathrm{~m}$ were initially established in a 23 ha area, in which all trees $\geq 20 \mathrm{~cm}$ diameter at breast height were marked, geo-referenced using a global positioning system, measured (canopy, $\mathrm{m}^{2}$, and height, $\mathrm{m}$ ) and identified to species level (A. López-Galindo \& P. QuintanaMorales unpubl. data).
Recording data. Focal animal observations were performed (Altmann 1974, Martin \& Bateson 1991). Each of the 4 ind. was followed for continuous $5 \mathrm{~h}$ sessions (07:00 to $12: 00$ and $12: 00$ to $17: 00 \mathrm{~h}$ ) during a period of 8 mo from September to December 2004 and from March to June 2005. Observations started the first day the group was released into the study site. In total, 400 observation hours were obtained, homogenously distributed among the 4 ind. We recorded the daily activity pattern (DAP) of each individual, including feeding, resting and movement episodes. Data collection followed the procedure applied in a previous howler monkey translocation study (Rodríguez-Luna et al. 2003).

Data analysis. All data were tested for normality using Shapiro-Wilk's test, revealing that data did not deviate from a normal distribution. A 1-way ANOVA was used to compare the time spent on each behavior between months and the time spent consuming different plant parts (mature leaf, fruit, young leaf, vine and stalk) between months. Diet was calculated by the frequency in which each tree species was used for feeding, and the time spent consuming each species was also recorded. All analyses were performed using Statistica for Windows, version 6.0 (StatSoft 2000). The group's home range size was calculated using the minimum convex polygon method in ArcView 3.2 (ESRI).

\section{RESULTS}

Of the 90 ha of space available, the released group used only 5.5 ha. The group's overall DAP time consisted of $64.1 \%$ spent resting, $25.6 \%$ feeding and $10.1 \%$ moving. Even though monthly variations were observed, the DAP structure was maintained (Fig. 1). Significant differences were found in the percentage of resting activity between months $(F=3.09$, $\mathrm{df}=7, \mathrm{p}=0.01)$; specifically between October and December (Tukey's test, $\mathrm{p}=0.02$ ). Significant differences were also found for feeding between October and May $(F=3.18$, df $=7, \mathrm{p}=0.01$; Tukey's test, $\mathrm{p}=0.04)$. No differences were found in time spent moving $(F=1.45, \mathrm{df}=7, \mathrm{p}=0.23)$.

We identified 26 plant species from 16 families consumed by the translocated group. Ficus lundelli comprised $48.2 \%$ of the total diet, followed by Inga tiboudiana (12.6\%) and Albizia purpusii (9.3\%). The combined total of these 3 species was $70.1 \%$ of the group's diet (Table A1 in the Appendix).

The diet of the group was composed of $45 \%$ mature leaves, $41 \%$ fruit, $10 \%$ young leaves, $3 \%$ vines and $1 \%$ stalks. Mature leaves and fruit were consumed most often in all months in similar percentages throughout the study. Young leaves were consumed mainly in April (Fig. 2). 


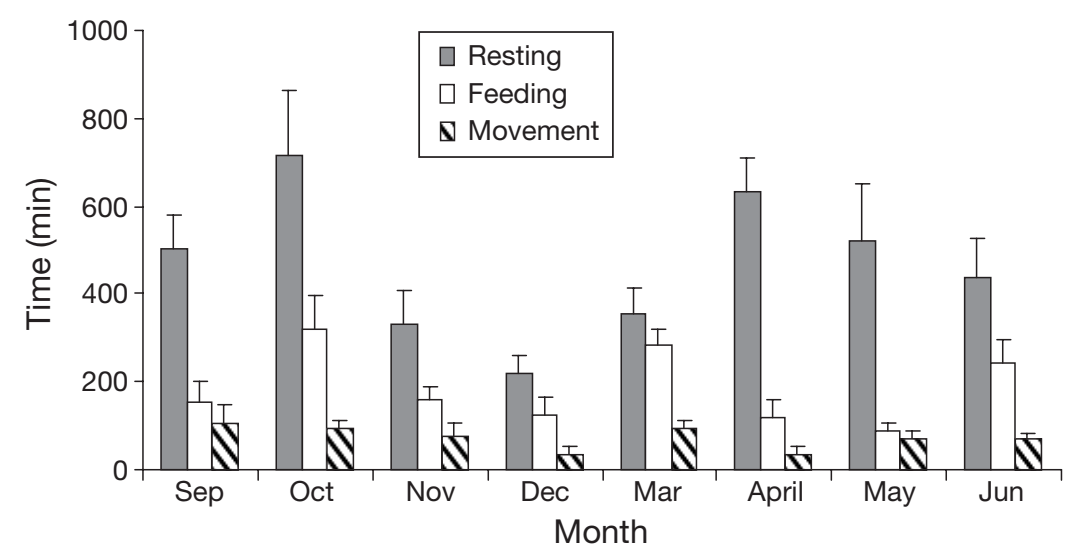

Fig. 1. Alouatta palliata. Monthly daily activity pattern of translocated howler monkeys. Data are mean (+SE) time spent on each activity per month

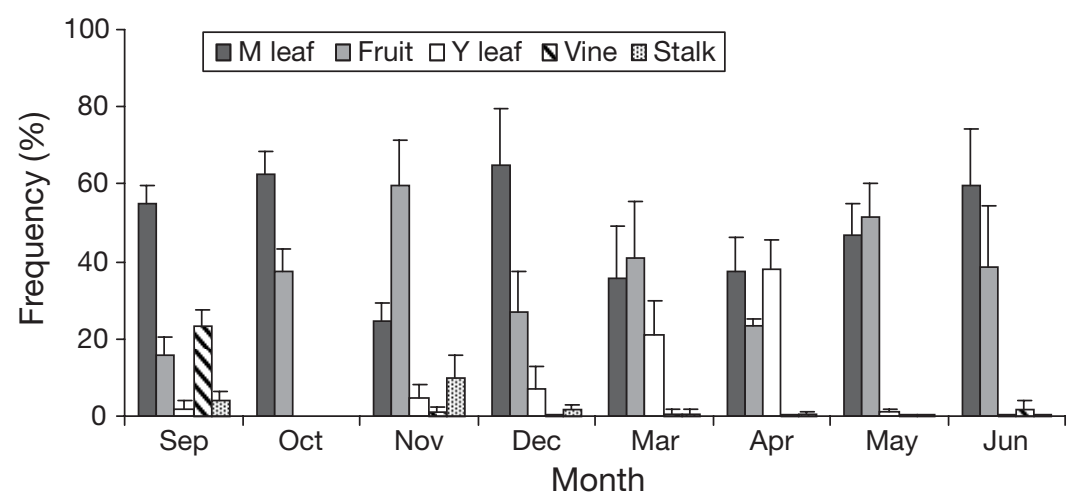

Fig. 2. Alouatta palliata. Frequency (\%) of plant part consumption by translocated howler monkeys. Data are monthly mean $(+\mathrm{SE})$ frequencies. Plant parts included: mature leaf (M leaf), fruit, young leaf (Y leaf), vine and stalk
2002). Time spent on feeding also varied between October and May. This may be related to an increase in fruit availability during May, which allows howler monkeys to spend less time feeding due to the nutritional content of fruits (Milton 1980).

The constant presence of humans at the release site, due to palm maintenance activities, did not have an obvious negative effect on the group's DAP. This illustrates that howler monkeys are able to co-exist closely with humans, as reported earlier by Estrada et al. (2006). This may be an important aspect to consider in conservation approaches for this species.

\section{Home range}

Previous studies have demonstrated that howler monkey groups can inhabit fragments between $<3$ and 60 ha (Cristóbal-Azkarate \& ArroyoRodríguez 2007), and have a great capacity to adapt to fragmented areas (Milton 1980, Stoner 1994, Crockett 1998, Onderdonk \& Chapman 2000, Clarke et al. 2002). Cristóbal-Azkarate \& Arroyo-Rodríguez (2007) found that fragment size is positively correlated with howler home range area; however, during the present study this correlation was not found, since the group only used $6.4 \%$ of the fragment. It can be assumed that the group found the necessary conditions for establishment in the area (e.g. food, resting sites and space),

Our results showed that the translocated howler monkeys maintained a constant DAP during the adaptation process. This DAP pattern matched with the activity patterns reported in other translocation projects (Serio-Silva 1992, Rodríguez-Luna 2000, Rodríguez-Luna et al. 2003), as well as for groups found in fragments within Los Tuxtlas (Table 1) (Estrada et al. 1999, Bicca-Marques 2003, Asensio et al. 2007).

Significant alterations in DAP time distribution, such e.g. prolonged periods of movement or rest, may indicate negative factors due to environmental conditions (e.g. food limitations) or human activities that impact on the primates' behavior (Milton 1998, Juan et al. 2000, Onderdonk \& Chapman 2000, Clarke et al. 2002, Cheyne et al. 2008). Significant differences in the proportion of time spent resting were found between October and December, possibly due to the rainy season, which can alter travel and/or feeding time (Clarke et al.
Table 1. Alouatta palliata. Ranges of mean daily activity patterns (DAP) registered for howler monkeys from other translocation projects and from free ranging groups in forest fragments in Los Tuxtlas are shown, providing references for the mean DAP results obtained in this study

\begin{tabular}{|c|c|c|c|}
\hline Resting & $\begin{array}{l}\text { DAP (\%) } \\
\text { Feeding }\end{array}$ & Movement & Source \\
\hline $69.0-78.6$ & $16.4-28.0$ & $0.5-0.9$ & Estrada et al. (1999) \\
\hline $66.3-69.8$ & $16.9-21.6$ & $12.1-13.3$ & $\begin{array}{l}\text { Serio-Silva (1992), } \\
\text { Rodríguez-Luna } \\
(2000), \text { Rodríguez- } \\
\text { Luna et al. (2003) }\end{array}$ \\
\hline $53.0-80.0$ & $16.0-24.0$ & $2.0-17.0$ & Bicca-Marques (2003) \\
\hline $55.1-69.1$ & $24.1-29.0$ & $6.27-14.34$ & Asensio et al. (2007) \\
\hline 64.1 & 25.6 & 10.15 & Present study \\
\hline
\end{tabular}


and as part of their strategy did not travel further, but used the resources found in a relatively small home range of 5.5 ha. Nevertheless, as the group grows and food resources become limited, the group may expand their present home range. Further studies are required to corroborate this supposition.

\section{Feeding preferences}

The use of Ficus lundelli confirmed numerous reports that have indicated that Ficus ssp. is very important in the diet of howler monkeys (Bicca-Marques 2003, Cristóbal-Azkarate \& Arroyo-Rodríguez 2007). This may be attributed to the multiple resources Ficus spp. produce year round (Milton 1991, Estrada 1984), their nutritional content (Milton 1980) and their asynchronous phenological cycles (Shanahan et al. 2001). The reduced number of food species used may be an indicator of the group's successful adaptation process, since previous reports have indicated that howler monkeys in Los Tuxtlas increase the number of species that compose their diet in order to cope with habitat alterations (Cristóbal-Azkarate \& Arroyo-Rodríguez 2007, Dunn et al. 2009).

\section{Further considerations}

The released group showed similar behavioral traits as documented for howler groups in other habitat conditions, and displayed similar behavioural patterns as described for the species as a whole (e.g. DAP, feeding preferences and spatial use) (Onderdonk \& Chapman 2000, Bicca-Marques 2003, Marsh 2003). No evidence was found that the group had difficulties in identifying feeding sources or establishing their home range, and behavior was displayed in a typical pattern.

During the present study, 1 birth was registered as well as a possible pregnancy. In further observations (ongoing study), 3 more births were recorded, which could be an additional indication of the successful establishment of the group.

These initial results suggest that fragments used for sustainable cultivation activities can be compatible with management strategies (e.g. reintroduction) used for endangered species conservation. In this context, it is more likely that fragments will be maintained if they provide benefits for local inhabitants. This approach is particularly important in highly fragmented landscapes, such as in the Los Tuxtlas region. This landscape approach can be used for species management at a metapopulation scale, incorporating sustainable use of some of the available habitat. Finally, the present study showed that translocation can be an effec- tive conservation tool for this species in the Los Tuxtlas region and demonstrated conservation alternatives under extremely complicated circumstances.

Acknowledgements. We acknowledge the grant to A.S.G. from CONACyT (registration 195409). We thank the owners of Flor de Catemaco for their support. We appreciate the comments and corrections of C. McSwiney and J. Vea on this manuscript. We also thank J. Dunn for his helpful revision and input.

\section{LITERATURE CITED}

Aguilar-Cucurachi S (2007) Respuesta conductual durante un proceso de translocación y metabolitos de corticosterona de un grupo de monos aulladores (Alouatta palliata) a través de cuatro ambientes (deteriorado, cautiverio, semicautiverio, libertad). MSc thesis, Universidad Veracruzana, Xalapa

Allen WH (1994) Reintroduction of endangered plants. Bioscience 44:65-68

Altmann J (1974) Observational study of behavior: sampling methods. Behavior 49:227-267

Asensio N, Cristóbal-Azkarate J, Dias PAD, Vea-Baro JJ, Rodríguez-Luna E (2007) Foraging habits of Alouatta palliata mexicana in three forest fragments. Folia Primatol 78: $141-153$

Bicca-Marques JC (2003) How do howler monkeys cope with habitat fragmentation? In: Marsh LK (ed) Primates in fragments: ecology and conservation. Kluwer Academics/ Plenum Publishers, New York, NY, p 283-303

> Cheyne SM, Chivers DJ, Sugardjito J (2008) Biology and behavior of reintroduced gibbons. Biodivers Conserv 17: 1741-1751

Clarke MR, Collins DA, Zucker EL (2002) Responses to deforestation in a group of mantled howlers (Alouatta palliata) in Costa Rica. Int J Primatol 23:365-381

Cristóbal-Azkarate J, Arroyo-Rodríguez V (2007) Diet and activity pattern of howler monkeys in Los Tuxtlas, Mexico: effects of habitat fragmentation and implications for conservation. Am J Primatol 69:1013-1029

Crockett CM (1998) Conservation biology for the genus Alouatta. Int J Primatol 19:549-578

Cuarón AD, Shedden A, Rodríguez-Luna E, de Grammont PC, Link A (2008) Alouatta palliata ssp. mexicana. In: IUCN (ed) IUCN Red List of threatened species. Version 2010. Available at www.iucnredlist.org

> Dunn JC, Cristóbal-Azkarate J, Veà J (2009) Differences in diet and activity pattern between two groups of Alouatta palliata associated with the availability of big trees and fruit of top food taxa. Am J Primatol 71:654-662

Estrada A (1984) Resource use by howler monkeys (Alouatta palliata) in the rain forest of Los Tuxtlas, Veracruz, Mexico. Int J Primatol 5:105-131

> Estrada A, Coates-Estrada R (1996) Tropical rain forest fragmentation and wild populations of primates at Los Tuxtlas, Mexico. Am J Primatol 17:759-783

Estrada A, Solano SJ, Ortiz Martinez T, Coates Estrada R (1999) Feeding and general activity patterns of a howler monkey (Alouatta palliata) troop living in a forest fragment at Los Tuxtlas, Mexico. Am J Primatol 48:167-183

Estrada A, Saenz J, Harvey C, Naranjo E, Muñoz D, RosalesMeda M (2006) Primates in agroecosystems: conservation value of some agricultural practices in mesoamerican landscapes. In: Estrada A, Garber P, Pavelka M, Luecke L (eds) 
New perspectives in the study of Mesoamerican primates: distribution, ecology, behavior and conservation. Springer Science \& Business Media, New York, NY, p 437-470

Griffith B, Scott J, Carpenter J, Reed C (1989) Translocation as a species conservation tool: status and strategy. Science 245:477-480

Guevara S, Laborde J, Sánchez-Ríos G (2004) Los Tuxtlas: el paisaje de la sierra. Instituto de Ecología A C, Unión Europea, Xalapa, Veracruz, p 87-90

Isabirye-Basuta G, Lwanga J (2008) Primate populations and their interactions with changing habitats. Int J Primatol 29: $35-48$

IUCN SSC (IUCN Species Survival Commission) (2002) Reintroduction Specialist Group: guidelines for nonhuman primate re-introductions. Re-introduction Specialist Group, IUCN, Gland

Juan S, Estrada A, Coates-Estrada R (2000) Contrastes y similitudes en el uso de recursos y patrón general de actividades en tropas de monos aulladores (Alouatta palliata) en fragmentos de selva en Los Tuxtlas, México. Neotrop Primates 8:131-135

Kowalewski MM, Zunino GE (1999) Impact of deforestation on a population of Alouatta caraya in Northern Argentina. Int J Primatol 70:163-166

Loudon J (2000) Diet, activity and ranging behavior of Alouatta pigra in Monkey River, Belize. MSc thesis, University of Calgary

Mandujano S, Escobedo LA, Palacios-Silva R, ArroyoRodríguez V, Rodríguez-Toledo EM (2006) A metapopulation approach to conservation of howler monkeys in highly altered landscape in Mexico. In: Estrada A, Garber PA, Pavelka M, Luecke L (eds) New perspectives in the study of Mesoamerican primates: distribution, ecology, behavior, and conservation. Kluwer Academic/Plenum Publishers, New York, NY, p 513-538

Marsh LK (2003) The nature of fragmentation. In: Marsh LK (ed) Primates in fragments: ecology and conservation. Kluwer Academics/Plenum Publishers, New York, NY, p 1-10

Martin C, Bateson P (1991) La medición del comportamiento. Alianza Universidad, Madrid, p 69-91

Milton K (1980) The foraging strategy of howler monkeys: a study in primate economics. Columbia University Press, New York, NY
Milton K (1991) Leaf change and fruit production in six neotropical Moraceae species. J Ecol 79:1-26

Milton K (1998) Physiological ecology of howlers (Alouatta): energetic and digestive considerations and comparison with the Colobinae. Int J Primatol 19:513-548

Olney PJ, Mace GM, Feistner A (1994) Creative conservation: interactive management of wild and captive populations. Chapman and Hall, London, p 265-286

$>$ Onderdonk DA, Chapman CA (2000) Coping with forest fragmentation: the primates of Kibale National Park, Uganda. Int J Primatol 21:587-611

Primack RB (1996) Lessons from ecological theory: dispersal, establishment and population structure. In: Falk D, Millar C, Olwell P (eds) Strategies for reintroduction of endangered plants. Island Press, Washington, DC, p 209-234

Rodríguez-Luna E (2000) Cambios en la estrategia de forrajeo del mono aullador (Alouatta palliata mexicana): estudio de una población en un fragmento de selva. MSc thesis, Universidad Veracruzana, Xalapa

Rodríguez-Luna E, Domínguez-Domínguez LE, MoralesMávil JE, Martínez-Morales M (2003) Foraging strategy changes in an Alouatta palliata mexicana troop released on an island. In: Marsh LK (ed) Primates in fragments: ecology and conservation. Kluwer Academic/Plenum Publishers, New York, p 229-249

Serena M (1995) Reintroduction biology of Australian and New Zealand fauna. Surrey Beatty and Sons, Chipping Norton, p 27-29

Serio-Silva JC (1992) Patrón diario de actividades y hábitos alimenticios de Alouatta palliata en semilibertad. BSc thesis, Universidad Veracruzana, Xalapa

> Shanahan M, So S, Compton SG, Corlett R (2001) Fig eating by vertebrate frugivores: a global review. Biol Rev Camb Philos Soc 76:529-572

Soulé M, Orians G (2001) Conservation biology: research priorities for the next decade. Island Press, Washington, DC, p 882-883

StatSoft (2000) STATISTICA for Windows. Computer program manual. Statsoft, Tulsa, OK

Stoner KE (1994) Population density of the mantled howler monkey (Alouatta palliata) at La Selva Biological Reserve, Costa Rica: a new technique to analyze census data. Biotropica 26:332-340 
Appendix. Table A1. Frequency of use of food species at the study site by the group of translocated howler monkeys Alouatta palliata. Values are presented as monthly and mean $( \pm \mathrm{SE})$ use throughout the study period, as well as the relative frequency $(\%)$ of use. Values in bold indicate the 2 most commonly consumed species

\begin{tabular}{|c|c|c|c|c|c|c|c|c|c|c|c|}
\hline \multirow{2}{*}{ Family } & \multirow[t]{2}{*}{ Species } & \multicolumn{8}{|c|}{ - Month } & \multirow[t]{2}{*}{ Mean } & \multirow{2}{*}{$\begin{array}{l}\text { Relative } \\
\text { frequency }\end{array}$} \\
\hline & & Sep & Oct & Nov & Dec & Mar & Apr & May & Jun & & \\
\hline Anacardiaceae & Spondias mombin & 0 & 4 & 0 & 2 & 2 & 2 & 1 & 5 & $2 \pm 0.62$ & 3.81 \\
\hline Annonaceae & Rollinia mucosa & 0 & 1 & 0 & 0 & 0 & 1 & 1 & 0 & $0.37 \pm 0.18$ & 0.71 \\
\hline Boraginacea & Cordia alliodora & 0 & 0 & 0 & 0 & 5 & 0 & 0 & 0 & $0.62 \pm 0.62$ & 1.19 \\
\hline Burseraceae & Bursera simaruba & 0 & 4 & 0 & 2 & 2 & 0 & 2 & 0 & $1.25 \pm 0.52$ & 2.38 \\
\hline \multirow[t]{2}{*}{ Cecropiaceae } & Cecropia obtusifolia & 14 & 1 & 0 & 4 & 3 & 0 & 0 & 0 & $2.75 \pm 1.69$ & 5.25 \\
\hline & Coussapoa purpusii & 0 & 1 & 0 & 0 & 3 & 0 & 0 & 0 & $0.50 \pm 0.37$ & 0.95 \\
\hline \multirow[t]{2}{*}{ Euphorbiaceae } & Robinsonella mirandae & 0 & 0 & 0 & 0 & 0 & 0 & 3 & 0 & $0.37 \pm 0.37$ & 0.71 \\
\hline & Tetrorchidium rotundatum & 0 & 0 & 0 & 0 & 1 & 0 & 0 & 0 & $0.12 \pm 0.12$ & 0.23 \\
\hline \multirow{3}{*}{ Fabaceae } & Dalbergia glomerata & 11 & 2 & 0 & 0 & 1 & 3 & 0 & 0 & $2.12 \pm 1.37$ & 4.06 \\
\hline & Platymiscium pinnatum & 0 & 0 & 0 & 0 & 2 & 0 & 0 & 0 & $0.25 \pm 0.25$ & 0.47 \\
\hline & Vatairea lundelli & 2 & 2 & 0 & 1 & 0 & 0 & 0 & 0 & $0.62 \pm 0.32$ & 1.19 \\
\hline Flacourtiaceae & Zuelania guidonia & 0 & 0 & 0 & 0 & 1 & 0 & 0 & 0 & $0.12 \pm 0.12$ & 0.24 \\
\hline Lauraceae & Ocotea rubiflora & 0 & 1 & 1 & 0 & 0 & 0 & 0 & 0 & $0.25 \pm 0.16$ & 0.47 \\
\hline Leguminosae & Erythrina folkersii & 0 & 0 & 0 & 0 & 0 & 0 & 0 & 2 & $0.25 \pm 0.25$ & 0.48 \\
\hline \multirow[t]{3}{*}{ Mimosaceae } & Albizia purpusii & 2 & 11 & 7 & 4 & 0 & 2 & 4 & 9 & $4.87 \pm 1.34$ & 9.3 \\
\hline & Inga aestuariorum & 0 & 0 & 0 & 0 & 0 & 0 & 4 & 0 & $0.50 \pm 0.50$ & 0.95 \\
\hline & Inga tiboudiana & 0 & 8 & 0 & 4 & 15 & 7 & 9 & 10 & $6.62 \pm 1.81$ & 12.65 \\
\hline \multirow[t]{4}{*}{ Moraceae } & Ficus lundelli & 18 & 35 & 20 & 12 & 37 & 39 & 21 & 20 & $25.25 \pm 3.59$ & 48.21 \\
\hline & Ficus perforata & 0 & 0 & 0 & 0 & 0 & 0 & 2 & 0 & $0.25 \pm 0.25$ & 0.47 \\
\hline & Ficus rzendowski & 6 & 0 & 1 & 0 & 0 & 0 & 0 & 0 & $0.87 \pm 0.74$ & 1.67 \\
\hline & Ficus yoponensis & 0 & 0 & 0 & 0 & 0 & 4 & 0 & 0 & $0.50 \pm 0.50$ & 0.95 \\
\hline Myrtaceae & Eugenia acapulcensis & 0 & 0 & 0 & 0 & 0 & 1 & 0 & 0 & $0.12 \pm 0.12$ & 0.23 \\
\hline Polygonaceae & Coccoloba hondurensis & 0 & 0 & 0 & 0 & 0 & 1 & 0 & 2 & $0.37 \pm 0.26$ & 0.71 \\
\hline Rutaceae & Zanthoxylum caribaeum & 0 & 2 & 0 & 0 & 0 & 0 & 0 & 0 & $0.25 \pm 0.25$ & 0.48 \\
\hline Sapotaceae & Sideroxylon portoricense & 0 & 0 & 1 & 0 & 0 & 2 & 0 & 0 & $0.37 \pm 0.26$ & 0.71 \\
\hline Ulmaceae & Trema micrantha & 3 & 1 & 1 & 1 & 0 & 0 & 0 & 0 & $0.75 \pm 0.36$ & 1.43 \\
\hline
\end{tabular}

Editorial responsibility: Anna Nekaris, Oxford, UK
Submitted: March 30, 2009; Accepted: April 13, 2010

Proofs received from author(s): May 26, 2010 